\begin{tabular}{|c|c|c|}
\hline Received: March 2019 & Accepted: Mei 2019 & Published: Juni 2019 \\
\hline \multicolumn{2}{|c|}{ Article DOI: http://dx.doi.org/10.24903/ jam.v3i2.497 } \\
\hline \multicolumn{2}{|c|}{} \\
\hline \multicolumn{2}{|c|}{} \\
\hline
\end{tabular}

\title{
Penguatan Daya Tahan Ekonomi Rumah Tangga Pelaku Industri Batubata Rakyat Melalui Usaha Budidaya Jamur Tiram
}

\author{
Ardi Novra \\ ardinovra@unja.ac.id \\ Universitas Jambi \\ Jul Andayani \\ Jul.andayani@yahoo.com \\ Universitas Jambi \\ Indra Sulaksana \\ indrasulaksana@unja.ac.id \\ Universitas Jambi
}

\begin{abstract}
Abstrak
Permasalahan utama yang dihadapi rumah tangga pelaku industri kecil dan menengah (IKM) batubata pada umumnya adalah frekuensi penerimaan yang tidak stabil dan cenderung dengan frekuensi waktu cukup panjang. Proses produksi batubata mulai dari penggalian tanah sampai siap jual membutuhkan waktu relatif cukup lama dan bahkan bulanan. Tujuan utama kegiatan adalah memperkuat daya tahan ekonomi rumah tangga pelaku IKM Batubata melalui diversifikasi usaha budidaya Jamur Tiram. Kegiatan menggunakan Pendekatan Partisipatif (Participatory Rural Appraisal) dengan Sistem Modal Bergulir Internal (Internal Revolving Capital System). Program penguatan daya tahan ekonomi rumah tangga pelaku IKM Batubata ini masih pada tahap pengenalan sehingga ruang lingkup kegiatan untuk sementara masih terbatas aspek budidaya. Pengembangan lanjutan pada masa akan datang akan mengarah ke sektor hulu (pembuatan baglot sebagai input primer dan sektor hilir berupa industri pengolahan hasil pasca panen. Program lanjutan pada masing-masing kelompok sasaran akan menggunakan sumberdana lain dan sangat tergantung pada motivasi dan keberhasilan program budidaya jamur tiram. Pelaksanaan kegiatan dilakukan melalui 4 (empat) tahapan yaitu tahapan persiapan, budidaya dan perguliran modal kelompok serta pelaporan. Berdasarkan evaluasi terhadap hasil kegiatan dengan berbagai kendala teknis dan non-teknis yang dihadapi selama proses pelaksanaan, maka dapat disimpulkan bahwa program pengabdian kepada masyarakat ini belum memberikan hasil optimal bagi penguatan ekonomi rumah tangga dan usaha kelompok pengrajin batubata rakyat. Meskipun demikian, model pengembangan kumbung diatas kolam bekas galian (KBG) telah mampu menarik motivasi rumah tangga untuk memanfaatkan KBG mereka.
\end{abstract}

Kata Kunci: jamur, tiram, kolam, galian dan batubata 


\section{Pendahuluan}

Salah satu aktivitas ekonomi yang potensial menyebabkan gangguan habitat dan komunitas micro-arthropods tanah (kelimpahan, komposisi, keragaman tropik, pola penyebaran dan stabilitas) adalah industri batubata (Siti, 2008). Sebagaimana kegiatan penambangan lainnya, kegiatan penggalian tanah liat dalam industri batubata dapat menimbulkan kerusakan dan pencemaran yang bersifat tidak dapat berbalik (irreversible damages) atau sekali suatu daerah dibuka, maka akan berpotensi menjadi rusak selamanya (Suprapto, 2011). Pengusaha industri batubata memanfaatkan lahan bekas galian industri batubata sebagai lahan pertanian (sawah) dan perikanan dengan mempertimbangkan faktor penggunaan tenaga kerja, lama persiapan lahan, volume pupuk digunakan, lokasi lahan bekas galian industri batubata, daerah pemasaran (Fajri, 2011). Permasalahan utama yang dihadapi rumah tangga pelaku Usaha Kecil Mikro dan Menengah (UMKM) Batubata pada umumnya adalah frekuensi penerimaan yang tidak stabil dan cenderung dengan frekuensi waktu cukup panjang. Proses produksi batubata mulai dari penggalian tanah sampai siap jual membutuhkan waktu relatif cukup lama dan bahkan bulanan.

\begin{tabular}{clcc}
\hline \multirow{2}{*}{ No } & \multirow{2}{*}{ Jenis Kegiatan } & \multicolumn{2}{c}{ Waktu (Hari) } \\
\cline { 3 - 4 } & & Kemarau & Hujan \\
\hline 1 & Penggalian/Pengadaan Tanah & 1 & 1 \\
\hline 2 & Pengadukan Bahan Baku Cetak & 2 & 2 \\
\hline 3 & Pencetakan & 4 & 6 \\
\hline 4 & Pengeringan (Penjemuran) & 14 & 21 \\
\hline 5 & Penyusunan Tungku Bakar & 3 & 4 \\
\hline 6 & Pembakaran & 5 & 5 \\
\hline 7 & Pendinginan & 3 & 3 \\
\hline 8 & Pembongkaran & 36 & 3 \\
\hline & Jumlah & 35 \\
\hline
\end{tabular}

Tabel 1 Rangkaian Proses Produksi Batubata

Sumber: Hasil Wawancara Pelaku UKMK Batubata (2015)

Proses produksi batubata membutuhkan waktu satu sampai satu setengah bulan karena proses pengeringan (penjemuran) membutuhkan waktu lama terutama saat musim hujan. Pelaku UKMK Batubata masih mengandalkan pengeringan alami (cahaya matahari), sehingga tidak hanya membutuhkan waktu lama tetapi juga butuh areal cukup luas. Pada sisi lain, penguasaan terhadap lahan relatif rendah sehingga siklus produksi tidak dapat dioptimalkan guna meningkatkan skala produksi atau dengan kata lain akselerasi dan peningkatan kapasitas produksi sulit dilakukan. Pada proses pengeringan, tidak banyak aktivitas yang dilakukan oleh UKMK dan terbatas hanya pada pembukaan dan pemasangan tutup plastik susunan batubata yang dikeringkan dan persiapan pencetakan batu periode selanjutnya. Fluktuasi dan ketidakpastian frekuensi penerimaan rumah tangga pelaku UKMK Batubata akibat faktor internal dan belum akibat faktor eksternal yaitu fluktuasi permintaan pasar. Pasar produk batubata bersifat periodik, dimana ada periode waktu saat permintaan tinggi dan periode permintaan rendah. Periode permintaan tinggi dimulai pada pertengahan tahun sampai akhir tahun dimana proyek pembangunan mulai berjalan baik oleh pemerintah maupun dunia usaha. Pada saat permintaan tinggi, maka harga yang diterima pelaku UMKM Batubata cukup 
memadai yaitu sekitar Rp. 400 perbutir batubata tetapi upaya akselerasi volume produksi tidak dapat dilakukan secara optimal akibat faktor internal seperti uraian sebelumnya.

Pemeliharaan ikan di kolam bekas galian tanah Lio (pembuatan batubata) adalah suatu hal yang menarik, karena tidak perlu menggali tanah untuk membuat kolam ikan (Deptan, 2015). Pemanfaatan untuk budidaya ikan lebih menguntungkan karena biaya rendahnya biaya investasi dan kedalaman bekas galian industri batu bata yang memadai (Fajri, 2011). Pemanfatan untuk tanaman membutuhkan perbaikam faktor kendala seperti pengapuran dan penambahan bahan organik, penghancuran bongkahan lapisan padas, penggunaan metode mekanik dan vegetatif untuk penanggulangan erosi (Pratiwiningtyas, 2012). Budidaya jamur tiram bertujuan untuk produksi tubuh buah jamur yang bernilai ekonomis tinggi. Jamur tiram putih berwarna putih agak krem dengan diameter tubuh 3-14 $\mathrm{cm}$ dan memiliki miselium (Kurnianti, 2013). Budidaya jamur tiram putih mebutuhkan keahlian tetapi akan terasa mudah jika sudah dilakukan dan dengan dukungan ilmu pengetahuan sudah sangat berkembang baik (KSF, 2010). Jamur tiram termasuk jenis tanaman budidaya dengan masa panen cukup cepat yaitu 40 hari setelah pembibitan atau setelah tubuh buah berkembang maksimal sekitar 2-3 minggu (Syaifudin, 2013). Perkembangan tubuh buah jamur tiram yang maksimal ditandai dengan meruncingnya tepi jamur dan layak dipanen saat jamur berukuran cukup besar tetapi belum mekar penuh (belum pecah) agar tidak mudah rusak.

Keuntungan usaha budidaya Jamur Tiram Putih menurut KSF (2010) antara lain laba usaha terbilang besar, budidaya oleh petani masih jarang, permintaan pasar tinggi dan cenderung meningkat, tidak tergantung musim dan dapat diusahakan sepanjang tahun, tidak terlalu membutuhkan skill tinggi, bahan baku mudah tersedia dan harganya murah, proses pemeliharaan mudah dan tidak butuh lahan luas, peluang stagnasi pasar kecil karena merupakan konsumsi sehari-hari dan merupakan pangan alternatif yang lezat, sehat dan bergizi, ramah lingkungan, dan bekas media tanam dapat digunakan sebagai pupuk kompos untuk kolam ikan, campuran pakan ikan/ternak, dan media memelihara cacing. Berdasarkan uraian diatas maka dilakukan kegiatan PPM dengan tujuan untuk memperkuat daya tahan ekonomi rumah tangga pelaku industri batubata rakyat melalui diversifikasi usaha budidaya Jamur Tiram. 


\section{Metode}

\section{Pendekatan dan Mekanisme Pengelolaan}

Kegiatan menggunakan Pendekatan Partisipatif (Participatory Rural Appraisal) dengan Sistem Modal Bergulir Internal (Internal Revolving Capital System)

\section{Foto 1 Pendekatan Partisipatif dan Sistem Dana Guliran Internal}

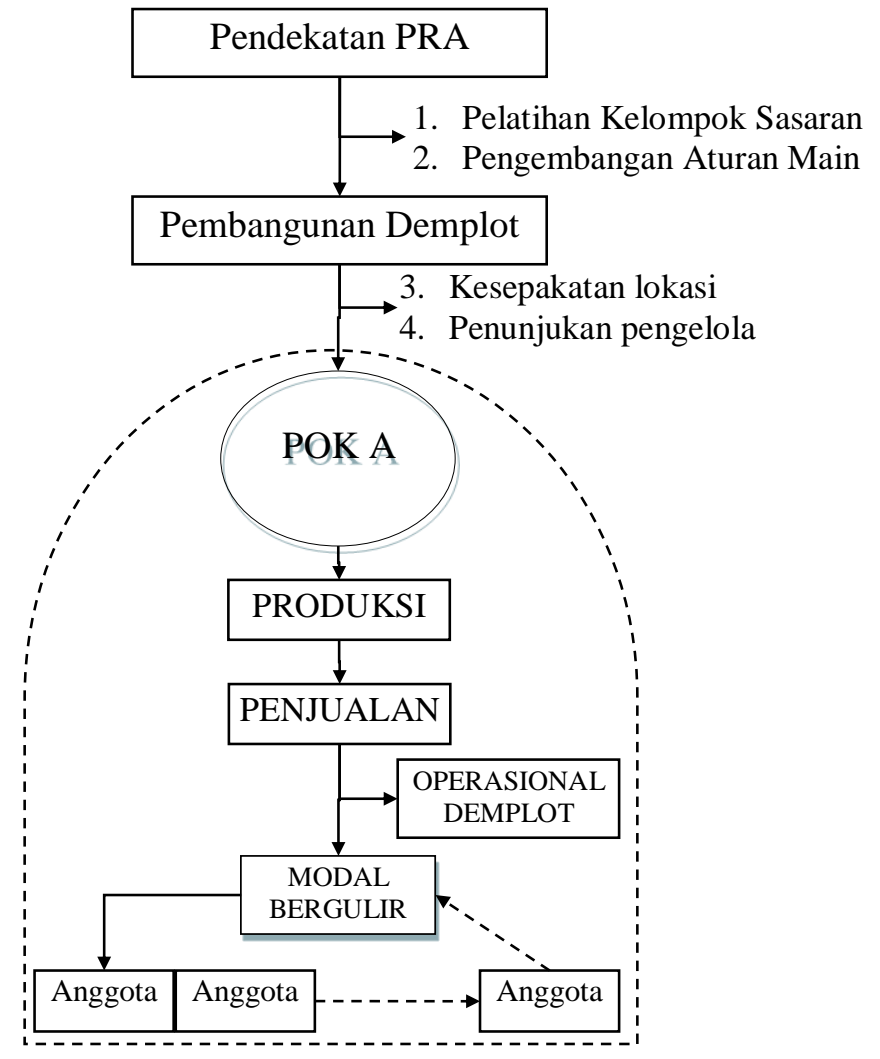

\section{Ruang Lingkup dan Kelompok Sasaran}

Program penguatan daya tahan ekonomi rumah tangga pelaku UKMK Batubata ini masih pada tahap pengenalan sehingga ruang lingkup kegiatan untuk sementara masih terbatas aspek budidaya. Pengembangan lanjutan pada masa akan datang akan mengarah ke sektor hulu (pembuatan baglot sebagai input primer dan sektor hilir berupa industri pengolahan hasil pasca panen. Program lanjutan pada masing-masing kelompok sasaran akan menggunakan sumberdana lain dan sangat tergantung pada motivasi dan keberhasilan program budidaya jamur tiram.

\section{Tahapan Pelaksanaan Kegiatan}

Pelaksanaan kegiatan dilakukan melalui 4 (empat) tahapan yaitu tahapan persiapan, budidaya dan perguliran modal kelompok serta pelaporan dengan rincian sebagai berikut:.

\section{Tahap Persiapan}

1. Koordinasi tim pelaksana kegiatan dengan kelompok mitra binaan program pemberdayaan

2. Survey lokasi dan kelayakan areal pengembangan demplot budidaya Jamur Tiram pada masing-masing kelompok mitra binaan 
3. Penyiapan dan pembangunan sarana prasarana demplot budidaya Jamur Tiram untuk masing-masing kelompok mitra binaan, antara lain

- Pembangunan rumah/kumbung Jamur Tiram dengan luas 4 x 4 meter pada masingmasing lokasi demplot kelompok mitra binaan

\section{Foto 2 Kumbung dan Rak Jamur Tiram}

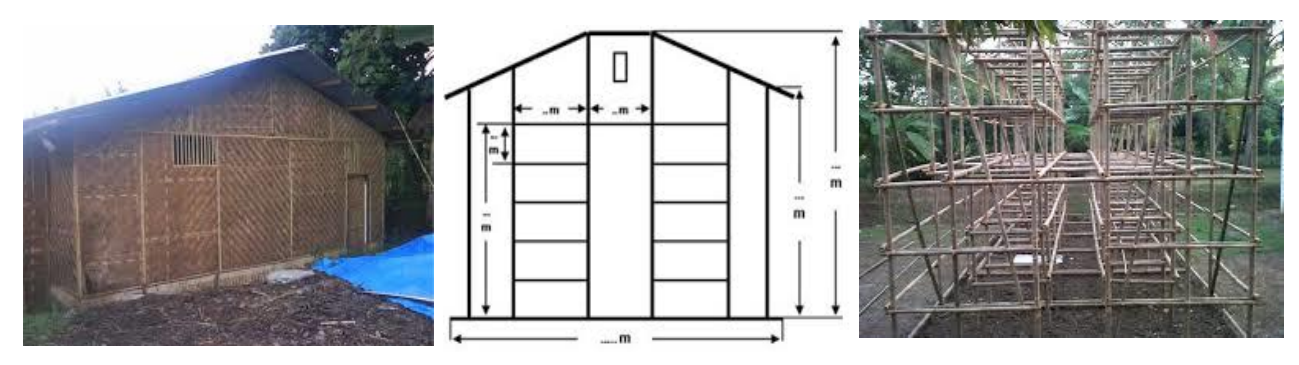

- Pembangunan rak baglog Jamur Tiram dengan jarak antar rak 1 meter, lebar rak $20 \mathrm{~cm}$ dan ketinggian 2 meter (terdiri dari 3 lapis rak).

4. Inkubasi rumah jamur/kumbung dan menjaganya supaya tetap kering dan bersih, suhu 22 $-28^{\mathrm{O}} \mathrm{C}$ tanpa cahaya.

5. Pengadaan dan penyusunan baglog Jamur Tiram (masing-masing 3.000) untuk setiap kumbung jamur kelompok mitra binaan.

6. Pembukaan baglog substrat dan cincin pada hari ke 7 atau maksimal 15 hari setelah inkubasi

\section{Tahapan Budidaya}

1. Penyiraman bakal buah tumbuh dan kumbung jamur menggunakan air bersih untuk mempertahankan suhu dan kelembaban ruangan yaitu $16-22^{\circ} \mathrm{C}$ dan $80-90 \%$ (Syaifudin, 2013).

2. Panen dapat dilakukan setelah 1,5 bulan dengan frekuensi 2 - 5 kali/minggu sebanyak 9 kali/periode budidaya tergantung cara pemeliharaan/penyiraman dan kebersihan kumbung dari sisa panen.

\section{Tahapan Redistribusi atau Perguliran Modal}

1. Hasil penjualan Jamur Tiram yang diproduksi akan menjadi sumber modal bergulir internal kelompok dengan sistem alokasi sesuai kesepakatan, yaitu:
a. Bagian penjualan yang dialokasikan untuk pengelola
b. Bagian penjualan yang dialokasikan untuk operasional
c. Bagian penjualan yang dialokasikan untuk model bergulir

2. Bagian yang dialokasikan untuk modal bergulir ditujukan untuk pengadaan baglog dan rumah tangga sasaran yang akan menerima guliran berkontribusi membangun sendiri rumah/kumbung Jamur Tiram. 


\section{(A) ABDIMAS \\ https://journal.uwgm.ac.id/index.php/abdimasmahakam \\ E-ISSN : 2549-5755 \\ Juni 2019, Vol. 3 No. 02}

\section{Hasil dan Pembahasan \\ Gambaran Umum Wilayah dan Kelompok Sasaran}

Kecamatan Jambi Luar Kota (Jaluko) dengan ibukota Pijoan merupakan salah satu kecamatan terluas di Kabupaten Muaro Jamb, dan sebelum pemekaran merupakan desa pusat administrasi Pemerintahan Pembantu Kabupaten Batang Hari wilayah Timur. Pembentukan Kabupaten Muaro Jambi berdasarkan UU No. 54 tahun 1999 tentang pemekaran wilayah kabupaten/kota di Provinsi Jambi. Secara geografis wilayah ini berbatasan langsung dengan Kota Jambi dan merupakan Center Point Jalan Lintas Timur dan Barat sehingga secara ekonomis menjadikan salah satu pusat pertumbuhan. Batas-batas wilayah Kecamatan Jaluko adalah sebelah Utara berbatasan dengan Kecamatan Sekernan, sebelah Selatan dengan Kecamatan Mestong, sebelah Barat dengan Kecamatan Pemayung Kabupaten Batanghari, dan sebelah Timur dengan Kecamatan Telanaipura dan Kecamatan Kotabaru Kota Jambi.

Kawasan Setiti juga termasuk Lingkungan Daerah Operasi Kerja Pertamina Simpang Setiti dengan beberapa unit pengeboran dan pengumpalan minyak. Implementasi program CSR Perusahaan Migas masih terbatas pada pembangunan jalan masuk pada tahun 2009 dan setelah itu belum ada program lain terutama terkait pengembangan ekonomi produktif. Industri lain yang berkembang adalah UMKM Batubata yang umumnya diusahakan oleh etnis pendatang. Lokasi usaha rakyat ini berkembang pada 2 wilayah RT yaitu RT 08 dan 10 yang akan menjadi lokasi sasaran program pengabdian pada masyarakat ini. Sektor pertanian yang berkembang adalah perkebunan dengan komoditas utama karet dan kelapa sawit, tanaman sayuran dan perikanan.

Kelompok Pengrajin Batubata Sumber Urip didirikan pada tanggal 26 Juli tahun 2013 berdasarkan hasil musyawarah masyarakat di Dusun Suak Medang Desa Muaro Pijoan Kecamatan Jambi Luar Kota (Jaluko) Kabupaten Muaro Jambi. Wilayah operasional kelompok Sumber Urip yang secara legal formal disahkan melalui Keputusan Kepala Desa Muaro Pijoan No. 03 tahun 2013 tanggal 28 Juli 2014 tentang Pengesahan dan Pengukuhan Kelompok Pengrajin Batubata Sumber Urip. Pada awal berdirinya kelompok Sumber Urip terdiri dari 10 orang dan pada saat ini berkembang menjadi 18 orang dan dipisah menjadi 2 kelompok yaitu Sumber Urip I (RT 08) dan Sumber Urip II (RT 10).

Rata-rata kepemilikan lahan lokasi UMKM Batubata mencapai $1000-2000 \mathrm{~m}^{2}$ dengan tingkat produksi sekitar 12.000 - 20.000 batubata dalam setiap bulan. Lokasi usaha berbentuk pondok kayu beratap rumbia yang berfungsi sebagai tempat pencetakan dan pembakaran batubata, dan biasanya terpisah dari lokasi tempat tinggal (rumah). Penggalian bahan baku tanah menggunakan escavator yang disewa dari operator (biaya sewa Rp. 450.000 500.000/jam) dan proses pencetakan batubata telah menggunakan mesin. Lahan-lahan bekas galian tanah yang terbentuk, banyak dimanfaatkan oleh pelaku UMKM Batubata untuk kolam penampungan air dan bahkan menjadi tempat budidaya ikan. Pengeringan batubata yang telah dicetak masih dilakukan secara alami pada areal terbuka dengan mengandalkan panas matahari. Untuk melindungi dari hujan dan embun pada malam hari digunakan plastik sebagai penutup susunan batubata. 


\section{Pelaksanaan Kegiatan Tahap Persiapan}

Koordinasi dan sosialisasi kegiatan kepada kelompok sasaran telah disepakati tentang Kolam Bekas Galian (KBG) yang akan menjadi lokasi pengembangan Jamur Tiram. Berdasarkan hasil survey calon lokasi dan diskusi disepakati bahwa KBG layak sebagai lokasi pengembangan usaha jamur tiram kelompok. Kesepakatan lain bahwa dengan keterbatasan anggaran maka terjadi perubahan unit usaha yang akan dikembangkan yaitu dari awalnya 2 tempat dikurangi menjadi terpusat pada satu lokasi tetapi dengan luasan (skala) lebih besar. Luas rumah kumbung yang akan dibangun berukuran 4 x 8 meter yang akan terbagi 2 yaitu kumbung dan rak jamur yang terletak langsung diatas permukaan air KBG $(3 \times 8$ meter) dan sisanya untuk areal terbuka sebagai lokasi pengolahan yang terletak pada permukaan tanah sempadan KBG (1 x 8 meter). Tataruang dan letak bangunan kumbung jamur seperti ini ditujukan untuk memperkuat konstruksi dan memanfaatkan kelembaban KBG untuk optimalisasi pertumbuhan jamur tiram saat budidaya.

Pembangunan kumbung jamur tiram akan dilakukan secara swadaya oleh anggota kelompok sasaran kecuali untuk hal-hal tertentu yang membutuhkan keahlian seperti pemasangan kerangka kumbung. Untuk itu akan digunakan tenaga kerja tukang yang sudah berpengalaman dengan upah dan bahan dibebankan pada dana kegiatan. Sebagai panduan dalam pembangunan kumbung beserta rak jamur tiram, maka disepakati untuk membuat desain oleh tim pelaksana kegiatan

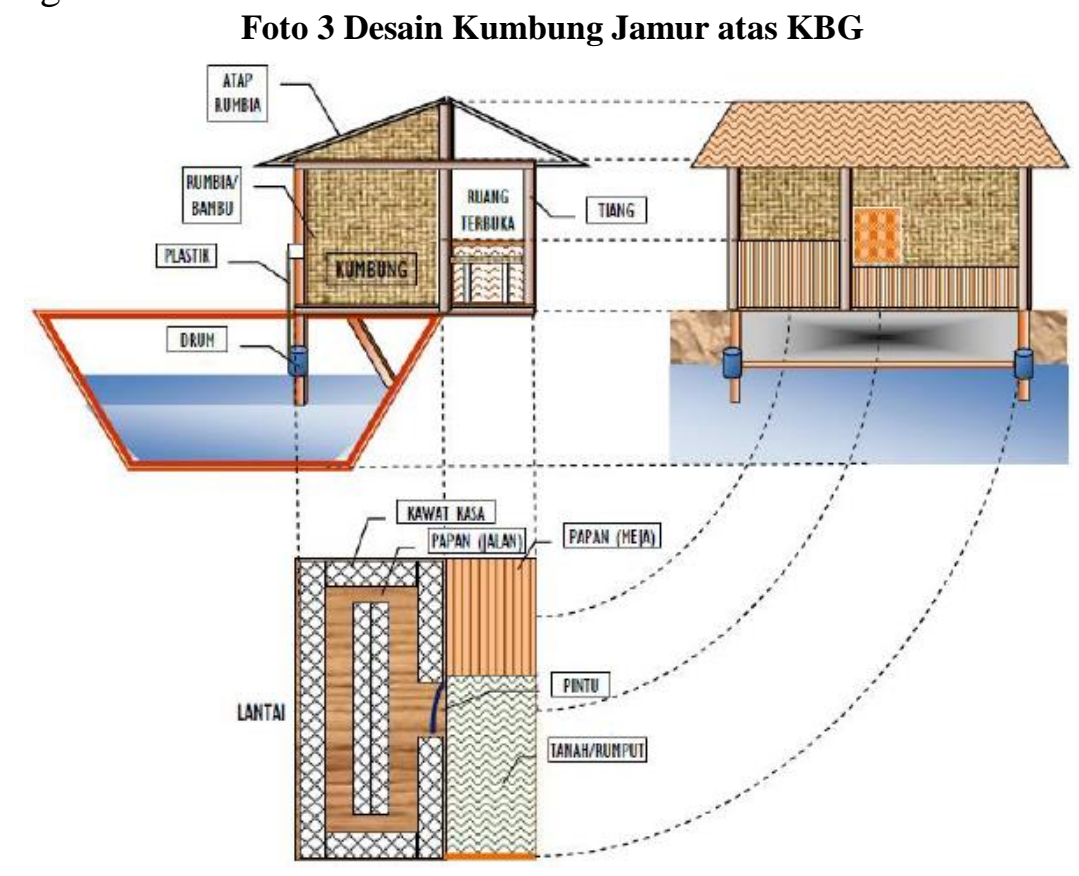

\section{Tahap Pembangunan Kumbung}

Pembangunan kumbung atas KBG sebagaimana disepakati dilakukan secara swadaya oleh kelompok pengrajin batu bata Sumber Urip dan seluruh material yang dibutuhkan ditanggung dana kegiatan. Pembangunan kumbung dilakukan secara bertahap dan membutuhkan waktu sekitar 2 (dua) minggu karena dalam pengerjaannya dilakukan secara bergiliran. Hal ini dilakukan agar proses pembangunan tidak menganggu kegiatan rutin para pengrajin yang tetap 
harus memenuhi kebutuhan belanja rumah tangga mereka. Tahapan-tahapan dalam pembangunan kumbung jamur yang dilakukan secara swadaya oleh kelompok sasaran

\section{Foto 4 Tahapan Pembangunan Kumbung}
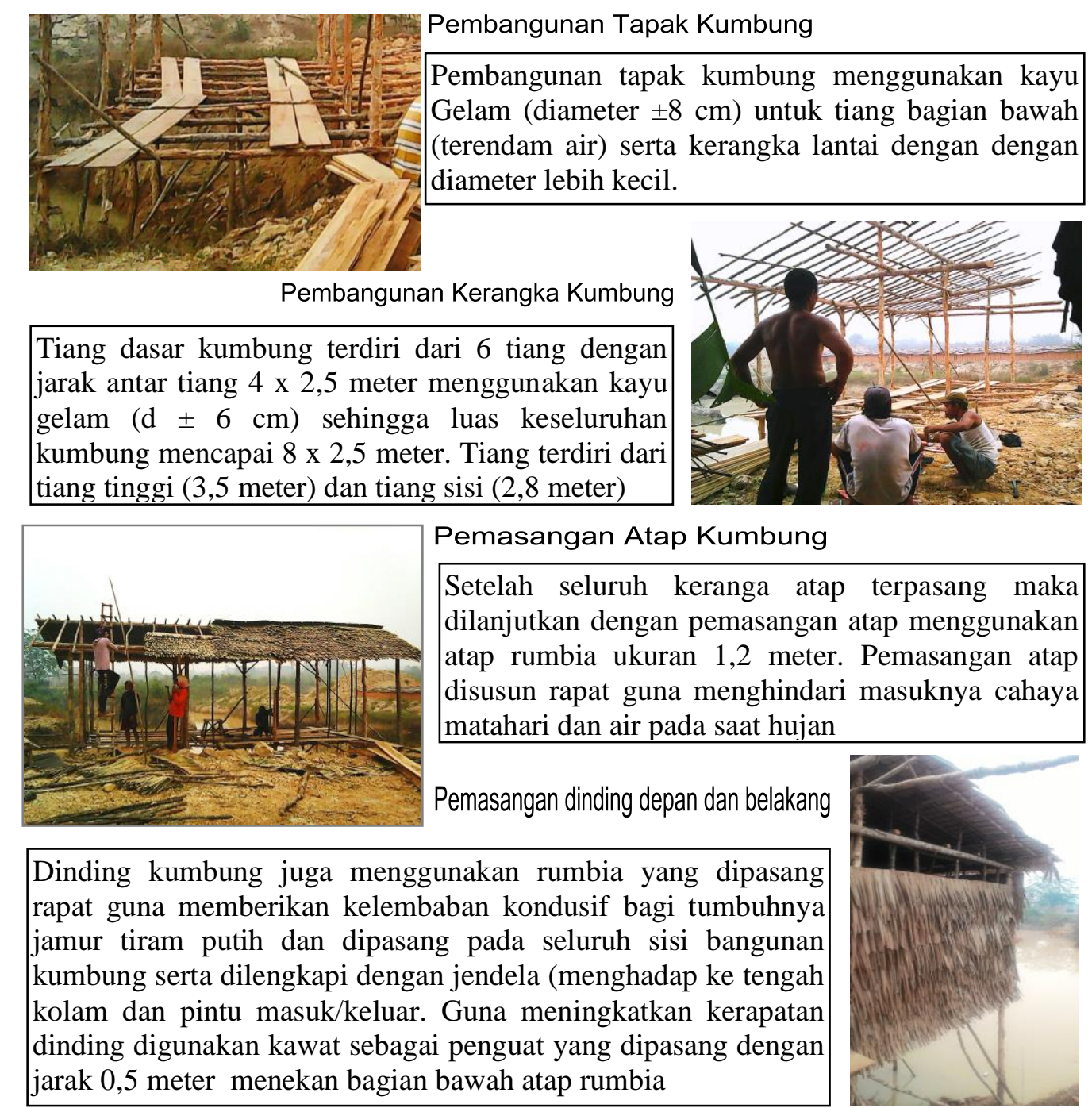

Dinding kumbung juga menggunakan rumbia yang dipasang rapat guna memberikan kelembaban kondusif bagi tumbuhnya jamur tiram putih dan dipasang pada seluruh sisi bangunan kumbung serta dilengkapi dengan jendela (menghadap ke tengah kolam dan pintu masuk/keluar. Guna meningkatkan kerapatan dinding digunakan kawat sebagai penguat yang dipasang dengan jarak 0,5 meter menekan bagian bawah atap rumbia

Pemasangan Lantai Kumbung

Pembangunan Rak Jamur

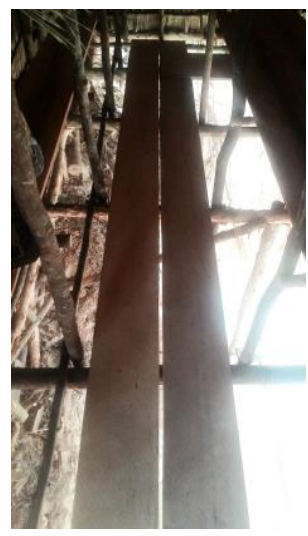
\begin{tabular}{l} 
Lantai kumbung menggunakan sepasang \\
papan dengan lebar $35 \mathrm{~cm}$ yang akan \\
digunakan sebagai jalan (aktifitas) dan antara \\
jalan papan tersebut dipasang kawat kasa \\
guna mencegah masuknya hewan liar. \\
\hline Pembangunan rak jamur dilakukan tepat \\
diatas bagian lantai yang terpasang kawat \\
kasa dengan lebar 2 x 35 cm (sesuai lebar \\
papan lantai rak). Rak jamur dibangun 3 \\
tingkat dengan jarak antar tiang penyangga \\
sekitar 2 meter
\end{tabular}

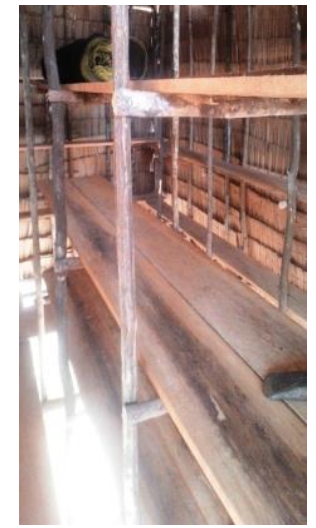


Pembangunan kumbung membutuhkan waktu sekitar 3 minggu dan dilakukan secara partisipatif dengan memanfaatkan waktu senggang anggota kelompok. Pada bagian luar kumbung (lantai diatas sempadan $\mathrm{KBG}$ ) yaitu pada bagian ruang terbuka dilengkapi dengan lantai kayu rapat dan bangku sebagai yang berfungsi sebagai tempat mempersiapkan kegiatan sebelum masuk kumbung, pengemasan hasil panen, istirahat dan menerima tamu yang berkunjung.

\section{Tahap Budidaya}

Sebelum baglog jamur tiram disusun dalam kumbung telah dilakukan persiapan dengan melakukan fumigasi bagian dalam dengan cara pengecatan kayu tiang dan lantai rak dengan kapur serta penyemprotan cairan fumigasi. Jumlah baglog jamur tiram yang dipesan pada tahap awal kegiatan adalah 1.000 baglog dari salah satu usaha baglog jamur tiram di Kota Jambi. Tahapan-tahapan budidaya yang dilakukan adalah:

1. Penyusunan baglog jamur tiram pada rak-rak yang telah disediakan sehari setelah pesanan baglog datang (terkendalam hujan lebat dan waktu maghrib). Proses penyusunan pada hari ke-2 dilakukan bersama-sama oleh anggota kelompok dengan tinggi susunan 3 lapis.

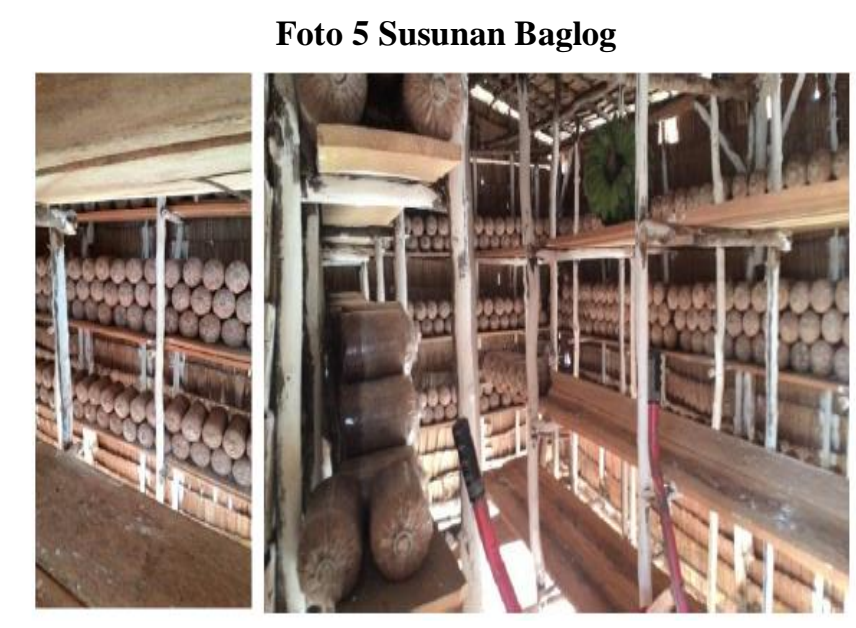

2. Pasca penyusunan pada rak jamur tiram dilakukan penyiraman (pengabutan) baglog dengan menggunakan hand dryer manual pada bagi depan depan (cincin dan kapas baglog).

3. Berdasarkan informasi dari produsen baglog (mempertimbangkan umur jamur dalam baglog) bahwa perawatan baglog pra-produksi ini membutuhkan waktu \pm 1 minggu dan setelah itu dilakukan baru bisa dilakukan tahapan pembukaan cincin dan kapas tutup baglog.

4. Pemeliharaan bibit baglog jamur tiram dilakukan dengan cara pengabutan dengan frekuensi 2 kali sehari yaitu pada siang dan sore hari selama 1 minggu sesuai informasi produsen.

5. Pengamatan terhadap pertumbuhan miselinium jamur tiram setelah 1 minggu perawatan yang masih belum berkembang baik (bintik-bintik putih) menyebabkan dilakukan penundaan pembukaan cincin dan kapas penutup baglog jamur tiram serta pelipatan plastik kebagian atas guna memberi peluang peningkatan serapan oksigen bagi pertumbuhan jamur. 
6. Pembukaan cincin dan kapas baglog baru dilakukan setelah 2 minggu proses penyusunan (jamur tiram masuk kumbung) dan sampai saat ini masih pada tahap menunggu tahap produksi.

\section{Kendala dan Rencana Tindak Lanjut}

Kendala yang dihadapi di lapangan, disamping kemunduran proses pelaksanaan akibat pencairan dana yang terlambat dan pemesanan baglog jamur yang membutuhkan waktu cukup lama (pengaruh musim kemarau) yang menyebabkan beberapa produsen baglog menghentikan sementara proses produksi. Order baglog yang sudah dilakukan sebanyak 1.000 kantong dari produsen yang belum memiliki jaminan kualitas produksi menyebabkan keterlambatan panen perdana untuk usaha kelompok yang dikembangkan. Untuk itu beberapa alternatif rencana tindak lanjut yang telah direncanakan adalah:

1. Pemesana kembali baglog jamur tiram sebanyak 500 kantong dari produsen lainnya karena ruang dan rak yang ada masih memungkinkan untuk penambahan kapasitas produksi (diperkirakan dapat mencapai 3.000 baglog).

2. Rencana pengembangan produksi baglog secara mandiri dengan terlebih dahulu mempersiapkan bangunan kedap guna produksi baglog. Proses persiapan baru sebagian dilaksanakan sehingga belum dapat direalisasikan sampai pada saat pelaporan ini.

3. Pengajuan proposal pemberdayaan masyarakat program IPTEKDALIPI 2016 dan riset inovatif produktif sumber dana LPDP departemen keuangan telah memberikan harapan baru bagi pengembangan. Program penguatan ekonomi rumah tangga pengrajin batubata melalui ke-2 program ini antara lain mencakup pengembangan budidaya terintegrasi jamur tiram dan kolam ikan skala rumah tangga serta pengembangan usaha kelompok produksi baglog jamur tiram pada tahun anggaran 2016.

\section{Simpulan dan Rekomendasi}

Berdasarkan evaluasi terhadap hasil kegiatan dengan berbagai kendala teknis dan non-teknis yang dihadapi selama proses pelaksanaan, maka dapat disimpulkan bahwa program pengabdian kepada masyarakat ini belum memberikan hasil optimal bagi penguatan ekonomi rumah tangga dan usaha kelompok pengrajin batubata rakyat. Meskipun demikian, model pengembangan kumbung diatas kolam bekas galian (KBG) telah mampu menarik motivasi rumah tangga untuk memanfaatkan KBG mereka. Program ini telah menjadi embryo dan layak untuk ditindaklanjuti melalui program lainnya baik dalam bentuk riset (peneltiian) maupun pemberdayaan masyarakat. 


\section{Daftar Pustaka}

Deptan (Departemen Pertanian), 2015. Budidaya Ikan Patin Pada Bekas Galian Bata Merah, Artikel Surya Mina Farm (SMF) Sleman, Browsing: http://www. bibitikan.net/budidaya-ikan-patin-pada-bekas-galian-bata-merah/, Accesed Mei $20^{\text {th }}$ 2015.

Hidayat, H., M Indriastuti, F. Syafrina, S. D. Arismawati, dan B. Sembodo, 2006. Model Reklamasi Lahan Kritis Pada Area Bekas Penggalian Batu Bata, Jurusan Pengelolaan Hutan dan Konservasi Sumberdaya Hutan Fakultas Kehutanan, Universitas Gajah Mada, Yogyakarta.

Fajri, N. D., 2011. Pemanfaatan Lahan Bekas Galian Industri Batu Bata di Desa Jambidan Kecamatan Banguntapan Kabupaten Bantul. Thesis, Universitas Negeri Yogyakarta, Yogyakarta.

Istikarini, D. G., 2011. Ketersediaan Bahan Baku dan Prospek Pengembangan Usaha Pembuatan Baglog Jamur Tiram (Pleurotus sp.) di Danny's Mushroom. Skripsi Jurusan Sosial Ekonomi Pertanian Faperta Universitas Jember.

KSF (King Spora Farm), 2010. Cara Budidaya Jamur Tiram, Sentra Budidaya Jamur Tiram, Browsing: https;//kingsporafarm.blogspot.com/2010/08/king-sproa-farm.html, Accesed August $12^{\text {th }} 2010$.

Kurnianti N., 2013a. Persiapan Usaha Budidaya Jamur Tiram: https://plus.google. com/+Tanijogonegorodotcom, Accessed April $9^{\text {th }} 2013$.

-----------, 2013b. Teknik dan Budidaya Jamur Tiram, https://plus.google. com/+Tanijogonegorodotcom, Accesses April $9^{\text {th }} 2013$.

Pratiwiningtyas, R. 2012. Kesesuaian Lahan Bekas Galian Batu Bata Untuk Tanaman Pangan di Dusun Ngampon, Desa Sitimulyo, Kecamatan Piyungan, Kabupaten Bantul. Thesis, Fakultas Ilmu Sosial Universitas Negeri Yogyakarta, Yogyakarta.

Purwoko dan Y. Arkeman, 2004. Kelayakan Industri Kerupuk Jamur Tiram di Kabupaten Bogor Departemen Teknologi Industri Pertanian, Fakultas Teknologi Pertanian, IPB, J. Tek. Ind. Pert. Vol. 13(3), 83-91.

Retnaningsih, N, 2009. Kelayakan Finansial Budidaya Jamur Tiram di Desa Sugihan,Kecamatan Tengaran, Kabupaten Semarang, Fakultas Pertanian Universitas Veteran Bangun Nusantara Sukoharjo, Jawa Tengah: 
Siti, J. 2008. Komunitas Mikroarthropoda Tanah pada Rehabilitasi Lahan Bekas Galian Batubata: http://etd.repository.ugm.ac.id/index.php?mod= peneli

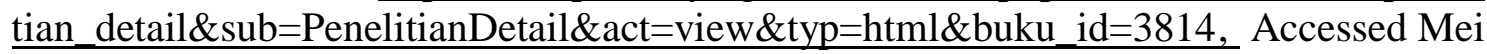
$20^{\text {th }} 2015$.

Syaifudin A., 2013. Proses Produksi Pada Budidaya Jamur Tiram, Blog Jamur Media: http://www.jamurpedia.com/blog/, Accessed March, 5 2013. 